\title{
Ribonuclease Gene
}

National Cancer Institute

\section{Source}

National Cancer Institute. Ribonuclease Gene. NCI Thesaurus. Code C25953.

Ribonuclease Genes encode (Ribo)nucleases that specifically catalyze the cleavage of phosphate ester linkages in ribonucleic acids; endoribonucleases cleave internal bonds and exoribonucleases cleave bonds at termini. $(\mathrm{NCl})$ 